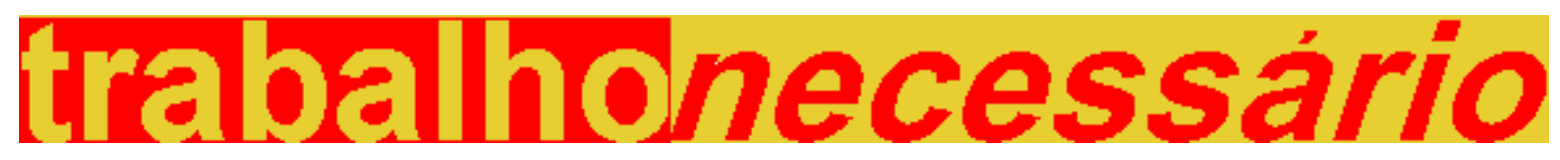

iss $\mathrm{n:} 1808-799 \mathrm{X}$

ano 2 - número 2 - 2004

\title{
ASPIRAÇÕES, INTERESSES E IDENTIDADE DOS TRABALHADORES. ELEMENTOS ESSENCIAIS À CONSTRUÇÃO DA HEGEMONIA[1]
}

Sonia Maria Rummert*

O conceito de hegemonia representa um dos pontos centrais no pensamento do gramsciano. Quando analisa os processos histórico-sociais, trata da formação e da importância dos intelectuais, desenvolve estudos sobre o Estado, aborda questões ligadas à literatura e à cultura em geral ou propõe estratégias de transição para o socialismo, Gramsci torna evidente a importância deste conceito como elemento essencial à compreensão de seu pensamento, afirmando que "a característica essencial da filosofia da práxis mais moderna consiste no conceito histórico-político de hegemonia" (GRAMSCI, Apud PORTELLI, 1977, p.61).

Para compreender, de forma mais ampla, o princípio gramsciano de hegemonia é necessário nos determos, primeiramente, na análise da estreita relação existente entre as concepções de hegemonia em Lênin e em Gramsci, já que é a Lênin que Gramsci atribui a formulação do princípio teórico-prático da hegemonia, afirmando ser esta " a contribuição teórica máxima de llitch (Lênin) à filosofia da práxis"(GRAMSCI, 1978, p.52).

O princípio da hegemonia em Gramsci e Lênin

Diversos estudiosos do pensamento marxista: Bobbio, Bucci-Glucksmann, Coutinho, Gruppi, Portelli, Tamburrano, entre outros, procuraram mostrar os pontos de aproximação e as distinções existentes entre os dois pensadores, apresentando sobre o assunto algumas divergências. Procuraremos aqui expor, resumidamente, alguns aspectos dessa questão, relevantes para melhor elucidar o princípio gramsciano de hegemonia.

O princípio da hegemonia que se encontra presente nos escritos de Lênin, embora este não o utilize explicitamente, refere-se, basicamente, à ditadura do proletariado e fundamenta-se na especificidade da história russa e na definição das tarefas políticas do 
proletariado. Tal princípio, embora construído em situação histórica distinta daquela vivida por Gramsci, forneceu a este os elementos básicos que lhe permitiram construir o próprio conceito, ampliando e enriquecendo a concepção leninista.

O que permite a Lênin e a Gramsci elaborarem, em situações históricas distintas, o conceito de hegemonia é a compreensão que ambos têm de que a sociedade é um todo orgânico e unitário, que se explica a partir da base econômica, mas que não pode ser reduzida inteiramente a ela, pois tal redução implicaria a negação da ação política e da própria hegemonia. Sobre esta questão Gramsci afirma: "é necessário combater o economicismo sobretudo na teoria e na prática política. Nesse campo, a luta pode e deve ser conduzida desenvolvendo o conceito de hegemonia" (GRAMSCI, 1980, p.38).

Outro relevante ponto de ligação entre ambos refere-se à importância dada às alianças de classes, que permite a mobilização da maior parte possível da população trabalhadora, oferecendo uma base sólida ao Estado proletário. Isto significa que a classe que orienta o novo processo hegemônico necessita apoiar-se em grupos aliados para sustentar a conquista e a efetivação da hegemonia.

Deve, ainda, ser ressaltado outro aspecto comum que reside na organização intelectual da hegemonia através do partido, o qual representa o verdadeiro sujeito revolucionário. Afirma Lênin que cabe ao partido intervir em todos os momentos da vida social e política e movimentar-se em todas as camadas da população, com o intuito de dar, aos operários, o conhecimento político necessário à luta pela conquista da nova hegemonia. Gramsci irá retomar quase inteiramente a concepção leninista do partido, embora dando maior ênfase à sua função educativa: "O moderno príncipe (o partido) deve e não pode deixar de ser o propagandista e o organizador de uma reforma intelectual e moral" (Idem, p.8)..

O conceito gramsciano de hegemonia está em alguns de seus fundamentos, bastante próximo da concepção leninista. Caberá a Gramsci, entretanto, aprofundá-lo e ampliá-lo, ligando-o não apenas ao nível da sociedade política como o faz Lênin, mas à primazia da sociedade civil e enriquecendo-o com o conceito de aparelho de hegemonia, como veremos posteriormente.

Não se pretende, aqui, desenvolver a análise comparativa entre o pensamento de Lênin e Gramsci, mas é pertinente transcrever o que afirma Bobbio sobre esta questão, uma vez que a síntese que nos apresenta possibilita a compreensão do amplo significado do princípio da hegemonia em Gramsci.

Para Bobbio, o fato de, em Lênin, preponderar o significado da direção política, pode ser explicado tomando-se as profundas diferenças entre os momentos históricos em que ambos elaboraram seus conceitos de hegemonia. Na verdade, a diferença essencial encontra-se

na extensão e, portanto, na função do conceito nos dois respectivos sistemas. Com relação à extensão, a hegemonia gramsciana (...) abarca, com suas entidades 
portadoras, não só o partido, mas todas as outras instituições da sociedade civil (entendida no sentido gramsciano) que tenham um nexo qualquer com a elaboração e a difusão da cultura. Com relação à função, a hegemonia não visa apenas à formação de uma vontade coletiva capaz de criar um novo aparelho estatal e de transformar a sociedade, mas também à elaboração e, portanto, à difusão e à realização de uma nova concepção de mundo (...) Nessa modificação de significado (...) reside a novidade do pensamento gramsciano de modo que hoje, apesar da homenagem que Gramsci presta a Lênin enquanto teórico da hegemonia, o teórico por excelência da hegemonia não é Lênin, mas sim Gramsci. (BOBIO, 1982, p.4648).

\section{O princípio da Hegemonia até 1926}

A compreensão da origem teórica do conceito de hegemonia requer, como nos mostra Bucci-Glucksmann (1980) que se identifique suas primeiras formulações, já implícitas na concepção do Estado e nas análises políticas apresentadas nos textos de Ordine Nuovo. Essas primeiras formulações estruturam-se gradativamente e, já em 1924, Gramsci elabora teoricamente as bases de seu princípio de hegemonia referindo-se à concepção leninista e apresentando a hegemonia como direção da classe operária, constituída de forma autônoma e independente e exercida num contexto de política de alianças: "A revolução apresenta-se praticamente como hegemonia do proletariado que guia o seu aliado: a classe camponesa" (Gramsci, A. Ordine Nuovo. Apud. BUCI-GLUCKSMANN, op. cit., p.231).

Em A Questão Meridional, Gramsci retoma as análises do Ordine Nuovo, enriquecendo-as. A hegemonia será, então, apresentada como a capacidade de compreender concretamente uma situação histórica, de identificar, na correlação de forças vigente na sociedade, aquelas que podem e devem ser mobilizadas na efetivação do processo revolucionário: "O proletariado pode e deve tornar-se classe dirigente e dominante na medida em que consegue criar um sistema de alianças de classe que the permita mobilizar contra o capitalismo e o Estado Burguês a maioria da população trabalhadora" (Gramsci, A. La Questione meridionale. Apud. Gruppi, 1978, p. 58).

\section{O princípio da hegemonia nos Cadernos do Cárcere}

O princípio da hegemonia sofrerá, ao longo do tempo, alterações que irão se configurar como uma ampliação do campo de análise, que deixará de estar circunscrito ao âmbito da ditadura do proletariado. Nos Cadernos do Cárcere, Gramsci passará a enfocar, de forma destacada, as práticas de construção e manutenção da hegemonia das classes dominantes, evidenciando a importância das questões ligadas à direção cultural e moral que essas classes imprimem ao todo social. Seu estudo virá, então, a englobar, progressivamente, as estruturas do Estado, vindo a enriquecer-se com um novo conceito: o de aparelhos de hegemonia.

Nos Cadernos, as análises sobre a hegemonia referem-se tanto à hegemonia burguesa quanto à hegemonia das classes subalternizadas. Ao referir-se à hegemonia burguesa $\mathrm{e}$ às práticas da classe dominante, seu intuito é o de aprofundar a análise do Estado 
moderno, fundado no modo de produção capitalista. Referindo-se à hegemonia das classes subalternizadas, Gramsci propõe estratégias que podem guiá-las em um processo de transformação revolucionária, a partir da criação de um novo bloco cultural, fruto de uma concepção de mundo unitária e coerente.

O princípio da hegemonia sublinha a grande importância da direção cultural e ideológica que a classe que é ou se propõe ser fundamental - hegemônica - imprime à ação das demais classes, exercendo, sobre estas, uma ação primordialmente educativa. A hegemonia de uma classe significa sua capacidade de subordinar intelectualmente as demais através da persuasão e da educação, esta entendida em seu sentido amplo. Gramsci enfatiza esta perspectiva afirmando que "Toda relação de 'hegemonia' é necessariamente uma relação pedagógica”(Gramsci, 1978, p.37)

Para conquistar a hegemonia é necessário que a classe fundamental se apresente às demais como aquela que representa e atende aos interesses e valores de toda sociedade, obtendo o consentimento voluntário e a anuência espontânea e garantindo, assim, a unidade do bloco social que, embora não seja homogêneo, se mantém, predominantemente, articulado e coeso. Isto significa que a classe hegemônica deve ser capaz de converter-se em classe nacional, isto é, na classe capaz de envolver toda a sociedade em um mesmo projeto histórico e capaz de assumir, como suas, as reivindicações das classes aliadas. Aqui fica clara a incompatibilidade existente entre hegemonia e corporativismo, como o próprio Gramsci nos mostra ao referir-se à hegemonia do proletariado: "O proletariado poderá desenvolver sua função dirigente tão somente se possuir um rico espírito de sacrifício e se for capaz de se libertar completamente de todo o resíduo de corporativismo reformista ou sindicalista" (Gramsci, A. Apud. Coutinho, 1981, p.57).

Ao afirmar que a classe hegemônica deve assumir, como suas, as reivindicações das demais classes, Gramsci aponta para a estreita relação entre hegemonia e economia. $\mathrm{Na}$ medida em que as expressões da vontade, os interesses e necessidades das classes aliadas são, na verdade, manifestações concretas das necessidades econômicas, geradas por determinado modo de produção, é preciso que a classe hegemônica, ao formular seu projeto econômico, considere estas necessidades, sem, entretanto, descaracterizar seu projeto fundamental de classe.

O fato da hegemonia pressupõe, indubitavelmente, que se deve levar em conta os interesses e as tendências dos grupos sobre os quais a hegemonia será exercida; que se forme certo equilíbrio de compromisso, isto é, que o grupo dirigente faça sacrifícios de ordem econômico-corporativa. Mas é também indubitável que os sacrifícios e o compromisso não se relacionam com o essencial, pois se a hegemonia é ético-política também é econômica; não pode deixar de se fundamentar na função decisiva que o grupo dirigente exerce no núcleo decisivo da atividade econômica (Gramsci, 1980, p.33).

A hegemonia pressupõe, assim, a capacidade da classe fundamental de dirigir as demais classes, calcada em sua condição de apresentar-se como classe nacional, que toma, 
como suas, as reivindicações das classes com as quais firmou compromissos e alianças, sem contudo, descaracterizar-se seu projeto hegemônico. A conquista da hegemonia, que envolve basicamente as superestruturas políticas e ideológicas mas não exclui a base material, deve anteceder a conquista do que Gramsci denomina de poder governativo, que virá coroar a luta hegemônica.

Entretanto, a distinção entre os momentos de construção da hegemonia e do poder apresenta basicamente um caráter metodológico. Na verdade, os dois momentos caminham passo a passo e se sustentam, e é apenas a conquista de ambos que dará a uma classe a supremacia sobre as demais. É o que fica claro na passagem de $O$ Ressurgimento

a supremacia de um grupo social manifesta-se de duas maneiras: como 'domínio'e como 'direção intelectual e moral'. Um grupo social é dominante dos grupos adversários que tende a 'liquidar' ou a submeter também com a força armada; e é dirigente dos grupos afins e aliados. Um grupo social pode e deve ser dirigente já antes de conquistar o poder governativo (esta é uma das condições principais para a própria conquista do poder); depois, quando exerce o poder, e mesmo se o tem fortemente na mão, torna-se dominante, mas deve continuar a ser também 'dirigente" (Gramsci, 1978, p. 276).

Nesta definição de supremacia de uma classe, em que direção e domínio se somam e se complementam, podemos destacar alguns pontos importantes cuja análise conduz a uma melhor compreensão do princípio da hegemonia.

Quando alerta para o fato de que a classe que exerce o poder deve, necessariamente, continuar exercendo sua função dirigente, Gramsci aponta para a questão da crise da hegemonia, para a análise do processo por meio do qual as hegemonias podem se constituir ou se dissolver.

Sendo a hegemonia a capacidade de determinada classe de manter unificado o bloco social por sua ação no campo ideológico, cultural e moral, é necessário que essa classe se apresente capaz de dirigir, de solucionar os problemas da sociedade, de manter articuladas as forças heterogêneas que compõem esse bloco social. Quando a classe que detém o poder perde sua capacidade de direção, tem contestada sua ideologia e não é mais capaz de justificar seu projeto político e econômico deixa, então, de ser hegemônica, perdendo sua supremacia. A partir daí a classe dominante poderá ainda deter o poder governativo, mas apenas sustentada pela dominação. "Se a classe dominante perde o consenso ela não é mais dirigente, mas exclusivamente dominante, detentora de coerção pura" (Gramsci. Apud Buci-Glucksmann, op. cit., p.80).

\section{A crise da hegemonia}

ocorre ou porque a classe dirigente faliu em determinado grande empreendimento pelo qual pediu ou impôs pela força o consentimento das grandes massas (como a guerra), ou porque amplas massas (especialmente de camponeses e de pequenos burgueses intelectuais) passaram de repente da passividade política a certa atividade e apresentam reivindicações que, no seu complexo desordenado, constituem uma revolução. Fala-se de 'crise de autoridade', mas na realidade, o que 
se verifica é a crise de hegemonia ou crise de Estado no seu conjunto (Gramsci,1980, p. 55).

Outra importante questão para a qual aponta a definição de supremacia de classe referese à relação entre direção-consenso e dominação-coerção. A afirmação de que a classe hegemônica "quando exerce o poder, e mesmo se o tem fortemente na mão, torna-se dominante, mas deve continuar a ser dirigente" nos permite compreender que a hegemonia, que legitima o poder de determinada classe, não exclui o domínio.

Analisando a situação de supremacia de uma classe podemos verificar que sua ação sobre as demais ocorre de dois modos diferentes: em relação às classes aliadas, a classe fundamental é dirigente e é dominante em relação às antagônicas. Aqui é importante ressaltar o caráter expansivo do princípio da hegemonia gramsciana: "toda força inovadora é repressiva em relação a seus adversários, mas na medida em que desencadeia, potencia e exalta forças latentes é expansiva e a expansividade é, em larga medida, seu caráter distintivo" (Gramsci, 1978, p.23). Dentro desta perspectiva, podemos compreender o verdadeiro sentido da coerção, que poderá assumir a função de complemento da hegemonia de uma classe que se proponha conduzir a sociedade na concretização de seu projeto societário.

A hegemonia, como vimos anteriormente, fundamenta-se, primordialmente, no consentimento "espontâneo" e "voluntário", isto é, no consenso, o qual assume significados diversos de acordo com as diferentes formas de relações de produção que uma dada hegemonia materializa. Uma classe, ao tornar-se hegemônica, deverá difundir e sustentar sua concepção de mundo, influindo em todos os aspectos da vida e do pensamento da sociedade, através do processo de difusão da ideologia que imprime características específicas à sua ação. Podemos dizer que um fator de distinção entre as diferentes formas hegemônicas consiste na ideologia que está subjacente a cada formação econômico-social.

Ao analisar o Estado moderno, Gramsci enfoca a hegemonia nas sociedades em que o modelo econômico fundamenta-se na separação entre o produto do trabalho e o próprio trabalho, nas relações de produção que alimentam os antagonismos de classe, ou seja, nas sociedades capitalistas. Nessas sociedades a reprodução das relações de produção apóia-se na hegemonia da classe dominante, que se mantém através do conformismo das classes subalternizadas à sua situação de classes exploradas.

Para garantir essa "hegemonia", a classe dominante conta com o poder de difusão ideológica situado no terreno da sociedade civil, por meio do que Gramsci denomina "aparelhos de hegemonia". Por meio desses aparelhos - escola, igreja, instituições de caráter artístico ou científico, meios de comunicação social etc. - efetivam-se as relações de hegemonia que, como vimos, são relações pedagógicas.

Em linhas gerais, podemos dizer que esta forma de relação "de hegemonia", ou 
pedagógica, que objetiva levar as classes subalternizadas a interiorizarem a concepção de mundo difundida pela classe dominante e a ignorarem a realidade de sua classe social, contribui, de forma decisiva, para a formação do homem-massa (Gramsci, 1978). Desse modo, "o poder social (...) aparece a estes indivíduos (...) como uma força estranha situada fora deles, cuja origem e cujo destino ignoram, que não podem mais dominar e que, pelo contrário (...) [torna-se] independente do querer e do agir dos homens e que, na verdade, dirige este querer e agir" (Marx e Engels, 1979. p.49).

Esta forma de exercício da hegemonia resulta do grau de capacidade que tem a classe dominante de unificar um bloco social marcado por profundos antagonismos de classe. Esse bloco social, para manter-se unificado, necessita que a classe dominante - por sua ação política, cultural e ideológica - mantenha articuladas as forças heterogêneas da sociedade, impedindo que os antagonismos de classe aflorem, vindo a provocar a recusa da ideologia dominante e gerando crises de hegemonia.

A análise que encontramos nos Cadernos sobre a questão da hegemonia não se prende, entretanto, apenas ao Estado capitalista, como já afirmado. Na verdade, o significado mais profundo da concepção gramsciana de hegemonia será encontrado nas referências à hegemonia das classes subalternizadas, nas propostas de estratégias que permitam viabilizar mudanças estruturais na sociedade, possibilitando a estas classes tornarem-se classes hegemônicas.

A hegemonia, em seu sentido revolucionário e expansivo, se traduz fundamentalmente numa reforma intelectual e moral:

o desenvolvimento político do conceito de hegemonia representa - além do progresso político-prático - um grande progresso filosófico, já que implica e supõe necessariamente uma unidade intelectual e uma ética adequadas a uma concepção do real que superou o senso comum e tornou-se crítica, mesmo que dentro de limites ainda restritos (Gramsci, 1978, p.21).

A conquista da hegemonia pelas classes subalternizadas configura-se, portanto, como um processo que implica a conquista da consciência política, a qual, por sua vez, possibilita a cada homem a conquista da autoconsciência, através da visão crítica de si mesmo.

Nesse sentido podemos identificar também uma distinção básica entre a hegemonia de uma classe que objetiva perpetuar a situação de exploração das classes subalternizadas e que perpetua, conseqüentemente, nessas classes, um estado de passividade moral e política e a hegemonia a ser conquistada pelas classes subalternizadas e que implica, necessariamente, uma profunda reforma intelectual e moral da sociedade.

Quando aborda questões referentes à hegemonia das classes subalternizadas, Gramsci refere-se, insistentemente, à unidade entre teoria e prática como fator essencial a qualquer projeto político que pretenda transformar a estrutura social. Esta unidade, geradora de uma ação coerente e consciente, só ocorrerá se as classes subalternizadas possuírem uma visão unitária e crítica dos processos sociais, uma vez que é precisamente a falta desta 
conexão entre teoria e prática que as caracteriza, enquanto tais. Possuindo uma concepção de mundo fragmentada e imobilizadas pela ausência de consciência crítica e pelo desconhecimento de que podem se constituir em sujeitos da história, as classes subalternizadas estarão impossibilitadas de se transformar em força hegemônica enquanto o processo de unificação entre teoria e prática não se desencadear.

Ao traçar as linhas gerais do processo de transformação das classes subalternizadas em classe hegemônica, fundado em uma nova concepção de mundo, Gramsci destaca a importância da ação daqueles que denomina de "intelectuais orgânicos", que irão dirigir a transformação e a construção de uma nova estrutura econômica e política e de uma nova orientação intelectual e moral;

uma massa humana não se 'distingue' e não se torna independente 'por si', sem organizar-se (em sentido lato); e não existe organização sem intelectuais, isto é, sem organizadores e dirigentes, sem que o aspecto teórico da ligação teoria-prática se distinga completamente em um estrato de pessoas 'especializadas' na elaboração conceitual e filosófica (Idem, p.21).

É aos intelectuais orgânicos, advindos das próprias classes subalternizadas e a elas estreitamente ligados, que caberá despertar, nessas mesmas classes, a verdadeira consciência social e o auto-conhecimento. Esta atribuição dos intelectuais orgânicos deverá efetivar-se no âmbito do partido, entendido por Gramsci como o grande "educador" das massas populares. O partido representa, na teoria gramsciana, o verdadeiro elemento aglutinador das massas, capaz de organizá-las num movimento de reforma intelectual e moral. Somente ele poderá conduzir a uma ação ampla de "caráter orgânico", "criadora" e "original", geradora de uma nova vontade coletiva que traçará novos caminhos históricos (Gramsci, 1980, p.6-7).

O partido assume, assim, o papel de sujeito revolucionário da história, com uma função orgânica, marcadamente ideológica, aglutinador de diversas frações da sociedade que apresentam interesses comuns. Este partido é

“constituído por uma 'elite' de homens de cultura, que têm a função de dirigir, do ponto de vista da cultura, da ideologia geral, um grande movimento de partidos afins (na realidade frações de um mesmo partido orgânico)" (Idem, p. 23).

Ao partido cabe, em última análise, o trabalho de conscientização das massas, organizando-as em torno de seu próprio projeto hegemônico, o que constitui passo decisivo na luta contra a hegemonia das classes dominantes.

A construção e a manutenção da hegemonia não podem prescindir dos "aparelhos de hegemonia", que contribuem de forma decisiva para a formação da opinião pública, na qual se situa a área e vinculação entre a sociedade civil e a sociedade política.

O que é chamado de 'opinião pública' liga-se estreitamente à hegemonia política, ou seja, é o ponto de contato entre a 'sociedade civil' e a 'sociedade política', entre o consenso e a força (...) A opinião pública é o conteúdo político da vontade política pública que poderia ser discordante; por isso, existe a luta pelo monopólio dos órgãos de opinião pública (jornais, partidos, parlamento), de modo que uma só força modele a opinião e, portanto, a vontade política nacional, dispersando os 
discordantes numa poeira individual e desorgânica (Gramsci, Apud. Coutinho, op. cit. , p. 199).

Neste ponto, a compreensão do princípio da hegemonia requer que analisemos o conceito de aparelho de hegemonia, que Gramsci introduz em sua obra ao enfocar, sobretudo, as práticas das classes dominantes no Estado Moderno.

\section{Aparelhos de hegemonia}

Ao referir-se às organizações que garantem a hegemonia de uma classe, Gramsci as denomina como organizações culturais que movimentam o mundo ideológico, órgãos de opinião pública, estrutura ideológica de uma classe dominante, aparelhos privados de hegemonia ou aparelhos de hegemonia, sendo, esta última, a expressão adotada neste trabalho. São aparelhos de hegemonia todos os canais que a classe dominante utiliza para, através do consenso, plasmar a consciência de toda coletividade, construindo e mantendo sua hegemonia.

O conceito de aparelho de hegemonia abrange o conjunto complexo de instituições da sociedade civil em suas múltiplas articulações e vários subsistemas: a igreja, o sistema escolar, os meios de comunicação, a organização cultural são alguns dos aparelhos que Gramsci identifica sem, entretanto, deixar de analisar a importância dos demais em seus estudos que objetivam compreender a

estrutura ideológica de uma classe dominante, a organização material destinada a manter, a defender e a desenvolver a frente teórica e ideológica (...) A imprensa é a parte mais dinâmica da estrutura ideológica, porém não a única. Tudo o que influi, ou pode influir, sobre a opinião pública direta ou indiretamente também o é; as bibliotecas, as escolas, as associações e os clubes de diferentes classes, a arquitetura, a disposição das ruas e até o nome das mesmas" (Gramsci, Apud. Manacorda, s/d., p.122-3).

O conceito de aparelhos de hegemonia irá qualificar e precisar a hegemonia de uma classe como direção política e cultural, compreendendo-se, desta forma, que a função dos mesmos é a de garantir a coesão do Estado de solidificar, através do consenso, o poder de determinada classe no bloco social. Na realidade, o verdadeiro significado da função dos aparelhos de hegemonia só pode ser encontrado a partir da referência direta à classe que se constitui em classe hegemônica e a partir da atuação dessa classe na sociedade civil. Ao analisar a organização da hegemonia nas sociedades capitalistas, Gramsci chega a estabelecer uma equivalência entre sociedade civil e aparelhos de hegemonia: "por Estado deve-se entender não somente o aparelho governamental, mas também o aparelho 'privado' de hegemonia ou sociedade civil"(Gramsci, Apud.:Bucci-Glucksmann, op. cit. , p.99).

Estando a expressão sociedade civil estreitamente ligada à idéia de direção cultural, de consenso, convém que retomemos uma questão já levantada anteriormente que trata da complementaridade entre direção e dominação. É importante relembrar que a dinâmica do pensamento gramsciano, assim como a dinâmica dos fatos sociais que ele analisa, não 
permitem que se estabeleçam fronteiras rígidas entre o campo de atuação da direção e da dominação. Embora os aparelhos de hegemonia se situem no âmbito da sociedade civil, estando, portanto, intimamente ligados à direção, poderemos verificar, através da análise de situações concretas que, onde prevalecem as ideologias arbitrárias, os limites entre sociedades civil e política estão pouco demarcados, verificando-se que, com freqüência, a segunda invade o terreno da primeira. Como exemplo podemos citar a atuação da censura que o Estado impõe aos meios de comunicação ou, como exemplo inverso, a polícia, diretamente ligada à dominação, que se mantém preocupada com sua imagem pública, visando a obter o consenso da sociedade.

O exercício da hegemonia nas sociedades fundadas na exploração de classes subalternizadas, na verdade,

caracteriza-se pela combinação da força e do consenso, que se equilibram variadamente, sem que a força suplante muito o consenso, ou melhor, procurando obter que a força pareça apoiada no consenso da maioria, expresso pelos chamados órgãos de opinião pública (...) os quais, por isso, em determinadas situações são artificialmente multiplicados (Gramsci, 1980, p. 116).

Nessa perspectiva, podemos compreender que os aparelhos de hegemonia estão profundamente marcados pela luta de classes, cabendo-lhes materializar a função educativa do Estado, exercendo um papel ideológico e político decisivo na unificação do bloco social.

A análise dos aparelhos de hegemonia aponta para a compreensão do sentido ampliado que Gramsci confere à concepção de Estado que, exercendo uma função educativa com o objetivo de dirigir a vida social, passa a ter um significado muito mais amplo na teoria marxista, ao apresentar-se como algo mais que uma instância monopolizadora dos meios de dominação e coerção.

A questão dos aparelhos de hegemonia está intimamente relacionada à concepção de cultura, que abriga os elementos essenciais à compreensão de sua função e de sua importância, tanto no modo de produção capitalista, quanto nas estratégias de que devem se valer as classes subalternizadas para conquistar a supremacia sobre as demais. Tal processo se inicia pela intervenção e conquista desses mesmos aparelhos de hegemonia ou pela criação de outros, cuja função primordial será a de promover a reforma intelectual e moral da qual advirá uma nova concepção de mundo.

O princípio da hegemonia, em Gramsci, que, por sua riqueza e complexidade exigiu uma exposição detalhada, ressalta, assim, a enorme importância das complexas questões referentes à ‘cultura e à ideologia. Consideramos que também possibilita a compreensão da pertinência da categoria projeto identificatório, que vem sendo por nós trabalhada nos últimos anos[2], como instrumento subsidiário de compreensão dos ricos processos de conquista e manutenção da hegemonia. É acerca de tal categoria que desenvolveremos os tópicos seguintes deste ensaio. 


\section{Projeto identificatório}

A análise dos projetos identificatórios[3] não pode prescindir, nos marcos do referencial teórico aqui adotado, das contribuições de Gramsci, que devem, necessariamente, ser consideradas quando pretendemos apreender a dimensão e a importância da ideologia (Rummert, 2000). Entretanto, é também necessário reconhecer que suas formulações trazem as marcas e os limites de um tempo e de uma realidade diversos da atualidade e que, também, apresentam fragilidades[4] decorrentes de uma visão de homem e de sociedade que a dinâmica do processo histórico demonstrou ser necessário superar.[5]

Um dos aspectos que pode contribuir para essa superação localiza-se, precisamente, na perspectiva a partir da qual se analisa a dinâmica dos processos de elaboração, apropriação e re-elaboração das ideologias. Nessa dinâmica, os limites demarcados pelas origens de classe são determinantes, mas entendemos não constituir o único aspecto explicativo da circulação, apreensão ou rejeição de idéias, valores e concepções que prevalecem tanto no plano interno de uma classe, ou de uma fração de classe, quanto em sua relação com as demais.

Gramsci já identificava a importância desses aspectos e procurou formular respostas para indagações tais como: "por que e como se difundem, tornando-se populares, as novas concepções de mundo?" (1978a, p.25). Entretanto, apesar de reconhecer que, no processo de construção de uma concepção de mundo, "a forma racional, logicamente coerente, a perfeição do raciocínio que não esquece nenhum argumento positivo ou negativo de certo peso, tem a sua importância, mas está bem longe de ser decisiva" (Idem, p.25), o pensador italiano explicava a adesão das massas populares a determinadas concepções remetendo ao que chamou de "elemento de fé" (aqui relacionado à religião laica).

É necessário destacar, também, a referência feita por Gramsci à importância do "contato sentimental e ideológico" que deve ser estabelecido entre "dominantes e dominados". Ressalta-se, assim, a necessidade de avançar a partir dessas reflexões, detendo-nos em reflexões que abarcam, também, o plano afetivo - das emoções -, que não se aparta do plano racional mas que é dotado de especificidades pouco analisadas ou não consideradas na maior parte da produção marxista.[6]

Ao analisar os movimentos sociais que eclodiram em São Paulo nos anos 1970, Eder Sader ressalta os limites dos estudos que tentaram explicar, por exemplo, a trajetória do movimento sindical brasileiro que deu origem ao novo sindicalismo - em particular no Estado de São Paulo -, como um processo reativo que emergiu, estritamente, dos padrões de acumulação capitalista vigentes naquele período. Por considerarem que as características políticas eram derivadas estritamente dos fatores econômicos, esses autores operaram a naturalização do econômico, fazendo as características políticas derivarem diretamente dele e, em decorrência, "pretendendo explicar os movimentos 
sociais por determinações estruturais", chegaram a impasses insolúveis (Sader, 1988, p.41).

Partindo dessas observações, o autor aponta para a importância de se desenvolver uma análise que objetive compreender o imaginário[7] desses movimentos, para captar-lhes a dinâmica e os aspectos que os tornam singulares. Konder também chama a atenção para a questão do imaginário, embora a partir de perspectiva diversa, quando assinala que uma das fragilidades do pensamento de Marx, no que tange à questão da ideologia, reside no fato de que o pensador alemão não enfrentou "as questões internas das 'estruturas mentais' ou a complexidade e a sutileza das representações e fantasias de que os homens se alimentam espiritualmente. Marx não se interessou pela 'longa duração' no imaginário coletivo" (Konder, 1992b, p.50).

Avançando no tema, Konder afirma que, ao contrário do que pode ser depreendido da clássica visão marxista sobre o imaginário, este não se restringe a uma expressão do arcaico que sobrevive na cultura de um povo. Embora esteja marcado pelo conformismo e pela estabilidade, no imaginário também estão presentes "as inquietações, os sonhos, as aspirações e os traços dos inconformismos" (Idem, p.41). Nesse sentido, Mendonça é bastante esclarecedora ao afirmar que a "dimensão cognitiva do imaginário não se extingue no papel da fantasia em remeter a processos passados, podendo ir mais além, constituindo a força motriz que impulsiona para uma ação voltada para o futuro" (s.d.. p.20).

A dimensão de futuro também está presente nas ideologias, uma vez que elas se mantêm a partir de um permanente processo de recriação, integrando as diversidades e renovando as interpretações da realidade no confronto do contato cotidiano. É precisamente esse processo que confere às ideologias uma dimensão prospectiva, uma vez que o que está em jogo é a legitimação da "ação presente em função de um futuro considerado desejável" (Ansart, 1978. p.40).

Podemos, assim, depreender que o imaginário não é, apenas, decorrente de uma cultura burguesa difundida em toda a sociedade, ou do atraso cultural de um grupo social, mas, ao contrário, integra a concepção de mundo de todas as frações de classe que formam a totalidade social, e muitos dos elementos que o constituem são, também, elementos formadores de vontades políticas coletivas, isto é, de forças sociais.

Todas as ideologias, seja qual for o seu grau de explicitação de conflitos (Ansart, 1978), abrigam representações, imagens, valores, projetos, padrões de comportamento e interdições. Tais elementos, entretanto, se considerados isoladamente, não constituem uma ideologia; elas se constituem no processo que envolve a seleção de diferentes manifestações desses elementos, as diversas formas de articulação dos mesmos, a rejeição de alguns e a re-significação de outros. É, precisamente, essa dinâmica de constituição que nos traz a importância do imaginário, uma vez que os símbolos e 
representações através dos quais as ideologias adquirem expressão, para serem acolhidos por aqueles que representam o objeto da ação de hegemonia, precisam estar, de forma direta ou indireta, vinculados a ele.

Esse processo, complexo e contraditório, ocorre, predominantemente, a partir das influências da base material, cujas manifestações de caráter econômico e social são vivenciadas pelo indivíduo e por sua classe. Entretanto, tal processo também se constrói a partir de motivações profundas que emergem da estrutura psíquica de cada um e do perfil psicológico de seu grupo e das características do imaginário de uma determinada sociedade.

O destaque dado, aqui, à questão do imaginário visa a introduzir, na discussão sobre a ideologia, uma perspectiva que avance em relação à idéia de classe social como único fator explicativo dos diferentes movimentos organizativos, das diversas formas de luta ou da emergência de forças sociais que ocorrem numa dada sociedade, bem como da adesão, em diferentes graus e formas, a projetos formulados para a totalidade social, ou para parte dela, pelas forças sociais dominantes.

Chegamos, assim, à concepção de classe enquanto fenômeno histórico, como nos é apresentada por Thompson, que alerta para o fato de que as concepções de classe social estão, muitas vezes, marcadas por um equívoco decorrente de "uma tentação generalizada em se supor que a classe é uma coisa" (1987, p.10-1). É a partir do equívoco que "coisifica" a classe trabalhadora que é possível "deduzir a consciência de classe que ela deveria ter (mas raramente tem), se estivesse adequadamente consciente de sua própria posição e interesses reais" (Idem, p.10). Ainda segundo Thompson, o real elemento definidor de uma classe é a ação dos homens no decorrer de sua própria história e, nesse sentido, as aspirações de uma classe, em um dado momento histórico, são válidas nos termos de sua própria experiência. São esses aspectos que irão definir, também, o grau e a forma da consciência de classe.

O primeiro estágio da formação da consciência é a percepção que ocorre, em primeira instância, a partir do espaço social em que estão inscritos indivíduos e grupos sociais. É nesse campo de experiência imediata - ou no plano fenomênico, como assinala Kosik (1978) - que as relações de classe são, genericamente, vivenciadas. Nesse sentido, a classe dominante possui seu campo de experiências, do mesmo modo que também possuem os seus próprios as classes subalternizadas. Tais campos não constituem blocos isolados e monolíticos; ao contrário, possuem múltiplos canais de interpenetração. É a existência de tais canais que aponta para a necessidade de consideramos a importância dos aspectos afetivos, fugindo de uma visão estritamente voltada para a consideração da dimensão cognitiva.

Ao analisarmos os temas da cultura e da ideologia numa perspectiva histórica, podemos reconhecer que, como assinalam Thompsom e Kosik, a coincidência entre o que deve ser 
percebido e o que é efetivamente percebido pelas classes subalternizadas está longe de ser automática. A análise do campo da experiência, nessa perspectiva histórica oferecenos um ponto de partida para compreender, à luz da categoria classe social, o funcionamento dos processos que levam, ou não, ao êxito dos recursos de construção e manutenção da hegemonia.

Retomando o afirmado anteriormente a respeito da potencialidade transformadora do imaginário, podemos, inclusive, lançar um olhar mais abrangente sobre o exemplo que nos é dado por Sader, ao referir-se à classe trabalhadora no Estado Novo. É inegável que o projeto identificatório levado aos trabalhadores pelo getulismo apresentava um caráter de convencimento, objetivando fazer com que interesses hegemônicos das frações da classe burguesa no poder fossem tomados, pelos trabalhadores, como seus próprios interesses.

Por outro lado, é inegável, também, que tal projeto não foi simplesmente imposto, mas incorporou diversos anseios que constituíram objeto de lutas e reivindicações dos trabalhadores desde a Primeira República. Assim, os direitos trabalhistas que marcaram aquele período e, mais que isso, a concepção de "trabalhador-brasileiro", então construída, não podem ser vistos como resultado de uma ação estrita da classe dominante, mas como expressão de uma luta cujas bandeiras, apropriadas pelas forças sociais que detinham o poder, foram forjadas pelos trabalhadores. Do mesmo modo, é importante assinalar que, para a maioria daqueles trabalhadores, houve um reconhecimento, um processo de identificação de suas aspirações no projeto hegemônico, tanto no plano racional quanto no afetivo, através de formas objetivas e subjetivas.[8]

O exemplo do Estado Novo permite depreender a importância da dimensão simbólica na difusão e consolidação de um projeto de sociedade que se torna hegemônico. Nesse sentido, os elementos fundadores das matrizes a partir das quais são elaborados os discursos são portadores de significados que encontram acolhida no imaginário de diferentes grupos sociais, repercutindo favoravelmente em relação aos projetos identificatórios hegemônicos ou potencialmente hegemônicos. É por encontrarem ressonância no campo cultural de uma dada sociedade - marcado pela complexidade e por contradições - e por constituírem seu sentido em um plano que não é regido unicamente pela racionalidade que os projetos hegemônicos se afirmam, superando os entraves que poderiam decorrer da heterogeneidade da totalidade social.

A ideologia, em seu sentido cultural e político, desempenha funções ordenadoras na sociedade, que se concretizam na medida em que são criados e amplamente difundidos discursos explicativos sobre a realidade que, apesar de suas variações, designam, a partir de um padrão comum de referências, problemas, objetivos e valores das diferentes frações das classes dominadas. Esse discursos, para terem assegurada sua inteligibilidade, se constróem a partir de um sistema de referências compartilhado pelo conjunto da sociedade. 
É no âmbito deste sistema de referências que os indivíduos e os grupos sociais se reconhecem a si próprios e, ao mesmo tempo se identificam como parte de um "nós" em que se percebem incluídos. A identidade significa, assim, um sentimento de "pertença" que pode ser organicamente construído ou atribuído do exterior - a um determinado grupo e a um determinado projeto.

Nesse sentido, a disputa pela hegemonia passa, necessariamente, pela elaboração, articulação e difusão de discursos capazes de ordenar aspirações, sonhos, fantasias projetivas, valores já consolidados, necessidades materiais e simbólicas e projetos coletivos em que os indivíduos se percebam contemplados. A elaboração desses discursos, em suas variações destinadas às diferenciadas frações de classe, é, fundamentalmente, pautada pelo projeto hegemônico, o qual desenha sua matriz e incorpora, de forma desarticulada e re-significada, elementos dos discursos opositores. É na complexidade esse processo que é construída e mantida a hegemonia, que analisamos anteriormente.

Efetivando-se no terreno do consenso e do convencimento, a ideologia hegemônica apela aos indivíduos e aos grupos visando a obter o que Gramsci denomina de consentimento ativo dos governados (1978). A idéia de consentimento ativo pode ser clarificada a partir da interpretação que nos é apresentada por Ansart, para quem o poder da ideologia reside, precisamente, em

transformar radicalmente a própria natureza do poder político, apagá-la ou velar sua potência coercitiva, transformar a relação de sujeição em relação de aliança no seio de uma ação compreendida, aprovada e efetuada. (...) A própria distinção entre dominantes e dominados, a significação desses termos desaparecem na aliança e na copresença de todos na identidade simbólica das práticas (Ansart, 1978, p.220).

individuais e coletivas de identidade, por meio de um projeto identificatório repleto de significados que permitem, a cada um, situar-se, simultaneamente, na complexa rede de relações sociais e afirmar-se individualmente como parte dessa sociedade, no mais das vezes sem perceber o papel de subalternidade que lhe é imposto.

O conhecimento sobre os processos de construção de identidades, bem como sobre a dinâmica da elaboração e difusão de projetos identificatórios, mostra-se, assim, essencial para que se obtenha uma compreensão mais ampla das forças sociais que estão, efetivamente, envolvidas nas disputas por hegemonia.

Para tanto, torna-se necessário considerar o fato de que a história das mentalidades coletivas apresenta ritmos de evolução quase geográficos. É uma "história que lida com fenômenos de uma persistência surpreendente na qual se identificam mitos arcaicos ressurgindo e influenciando comportamentos", como assinala Konder (1992a. p.8). Podemos crer que nesses ritmos geográficos das mentalidades pode ser encontrada uma das explicações para um comportamento social identificado por Gramsci e que consiste na resistência à mudança: "a multidão de cidadãos vacila e se assusta na incerteza ante o 
que poderia significar uma mudança radical". Dessa forma, qualquer mudança na ordem social assume o significado de "uma violenta desestruturação, não se vê a nova ordem possível, melhor organizada que a anterior" (Gramsci, 1978b, p.18).

A partir dessa perspectiva, torna-se possível perceber, nos modelos de identificação atualmente hegemônicos na sociedade brasileira, traços conservadores que se mesclam às profundas transformações que marcaram a história do século $X X$ e que constituem um expressivo exemplo da dialética entre continuidades e rupturas.

Essa dialética entre continuidades e rupturas, que marca os processos de elaboração dos projetos identificatórios hegemônicos, ou que se pretendem hegemônicos, pode ser compreendida a partir do estudo desenvolvido por Mendonça (s.d., p.24) sobre o discurso político hegemônico na Primeira República, no que diz respeito às concepções de modernização e de progresso, o qual nos oferece significativos exemplos de resignificações simbólicas, quando comparado ao atual momento histórico. Além de evidenciar a importância da dimensão simbólica na constituição e consolidação de projetos hegemônicos, destaca-se a possibilidade de transportar para a atualidade a análise desenvolvida, o que traz à luz a dinâmica da formação da cultura.

Mendonça toma como referência a aura de modernidade que marcou o mundo desde a segunda metade do século XIX, estendendo-se às primeiras décadas do século $X X$, e que se construiu sob a influência da eletricidade, das máquinas a vapor, do aço e do ferro, marcas do momento em que o capitalismo se afirmou em âmbito internacional. Nesse processo, um conjunto de eventos-monumento se destacou pela importância simbólica que assumiu. Foram as grandes exposições mundiais que, em suas diferentes dimensões, sempre colossais e solenes, revestiam-se de um caráter pedagógico, valorizador da racionalidade, da unidade, do congraçamento e da cooperação universais, da ciência e da técnica.

Nesse estudo, destacam-se pontos essenciais que permitem a compreensão do projeto identificatório hegemônico naquela época, em nosso país:

a) a enunciação, por parte do Estado e das lideranças a ele ligadas, "de um determinado futuro" (Idem, p.18) - revestido de positividade - realizável desde que se tomasse o progresso como referência fundamental das crenças e das ações;

b) o permanente exercício pedagógico de difusão de uma matriz de percepção da realidade, calcada na "clivagem entre moderno x arcaico, enquanto pensamento 'identificante'" (Idem, p.19), a ser apropriado por todos;

c) a construção de uma visão "mística da ciência e da técnica" (Idem, p.18), tomadas, em si, como universalizadoras das oportunidades e a apresentação das mesmas como epicentro de um

projeto idealizado, constituindo-se na introjeção coletiva de expectativas, padrões de comportamento e simbolizações culturais assimilados dos países centrais, sem os 
quais - supostamente - o lugar da 'nação' (...) no jogo internacional estaria ameaçado, por faltar-lhe a marca da pertinência à modernidade (Idem, p.21).

Com a marca dessas características, construiu-se o projeto identificatório hegemônico no país durante a Primeira República. Cabe, entretanto, ressaltar que sua formulação não representou o resultado de um plano maquiavélico, destinado, estritamente, a subjugar as forças sociais contra-hegemônicas. Esse aspecto, para o qual alertam Marx e Gramsci, é expresso por Mendonça ao afirmar que, na realidade,

O próprio processo de produção ideológica ao transformar o conteúdo latente (as contradições inerentes ao desenvolvimento do capitalismo no país) no manifesto (uma contradição novo $x$ velho), exercia uma espécie de fascínio coletivo, ativador de fantasias individuais que, ao transcenderem a determinação classista, garantiriam sua reprodução tão duradoura (Idem, p.19).

Por outro lado, recuperando a idéia, anteriormente exposta, de que no campo do imaginário convivem, dialogicamente, as dimensões de passado e de futuro, não podemos ignorar o fato de que a ilusão contida naquele discurso modernizador também propiciou condições concretas para a

realização dos desejos num futuro idealizado. (...) Investindo num futuro idealizado para a economia brasileira, nas trilhas da ciência e da tecnologia no campo, o discurso - pela via da ilusão - contribuía para reforçar a subordinação periférica, ao mesmo tempo que definia o papel político de pressão que garantiu a ampliação do poder de intervenção do Estado na economia antes mesmo de 1930 (Idem, p.23).

As ações visando a um futuro desejável estão fundadas no princípio de que cada futuro desejável abriga um projeto de sociedade e, conseqüentemente, um projeto identificatório, cujos elementos constitutivos devem repercurtir, positivamente, no imaginário para serem acolhidos e, também, para serem reconhecidos como expressão sistematizadora de aspirações que motivem para a adesão e para a luta visando a conquistá-lo. Ou seja, torna-se imprescindível que tais projetos lancem mão de "um sistema de referências compartido" (SADER, 1988, p.60). Ou ainda, como afirma Aulagnier, "pensar a realidade é dever pensar uma realidade que só podemos acreditar como tal na medida em que ela é também a realidade dos outros" (grifo da autora) (1985, p.25). Esse é um elemento essencial na conquista e manutenção da hegemonia, uma vez que acena, para a totalidade social e para cada indivíduo, com a possibilidade de conquista da felicidade.

Os exemplos históricos apresentados - o discurso modernizante da Primeira República e o trabalhismo no Estado Novo - ressaltam diferentes aspectos da constituição de projetos identificatórios, formulados visando à conquista de hegemonia, pelas frações de classe então detentoras do poder, sobre a totalidade social. Nos dois exemplos, destaca-se a importância da enunciação de sistemas de referência passíveis de serem compartilhados pelo conjunto da sociedade, como assinalado por Sader e repletos de elementos constitutivos difundidos amplamente, por meio da ação pedagógica exercida pelos diferentes aparelhos de hegemonia de que puderam valer-se as forças dominantes.

\section{Projeto identificatório neoliberal - novas investidas de "conquista" do trabalhador}


Como já foi destacado, a conquista e manutenção da hegemonia junto à classe trabalhadora não pode ficar restrita ao campo cognitivo. Ao contrário, e cada vez mais, em função dos avanços tecnológicos e das novas formas de organização do trabalho "o lugar do sujeito e das relações intersubjetivas [é] absolutamente central, na medida em que a mobilização psíquica do indivíduo, (...) constituiria a pré-condição mesma de toda atividade produtiva" (Hirarta, 1994, p.137). Assim, faz-se necessário construir um conjunto de valores, normas de comportamento, formas de representações do mundo e padrões de socialização que assegurem, ao Capital, que o trabalhador estará afetivamente comprometido com a produtividade e a competitividade da empresa.

Para tanto, impõem-se profundas mudanças, não só em relação à concepção de mundo de cada ao trabalhador, mas ao conjunto da sociedade. Tais transformações implicam a formação de um novo ambiente cognitivo e afetivo que transcenda o âmbito da empresa e se irradie pela totalidade social e, sobretudo, a difusão do "ethos empresarial"[9], (Rummert, 2000).

Trata-se, portanto, de tecer uma nova cultura, calcada nos valores empresariais, que têm sua centralidade na lógica do mercado, na ênfase no individualismo e na competitividade. Fugir a esse modelo é anacrônico, revela o descompromisso com o progresso do país e, em decorrência, torna-se constrangedor. Na realidade, o que se propõe é a construção de uma nova matriz explicativa das relações sociais fundadas no clássico antagonismo entre capital e trabalho, redefinindo os modos de pensar a sociedade e de nela viver, sem, contudo, subverter as bases de sustentação da estrutura dominante.

Esse novo tecido cultural, para concretizar-se, apresenta um requisito indispensável: o abandono do equívoco ideológico que coloca o antagonismo entre Capital e Trabalho como fundamento das relações sociais. No mundo moderno, esse antagonismo se dissipa, dando lugar às diferenças de subjetividade presentes, por exemplo, nas questões de raça, etnia e/ou gênero.

Tal concepção, que se apresenta como nova, constitui, entretanto, uma espécie daquilo que a teoria psicanalítica designa como retorno do recalcado. Ou seja, recorrentemente, o Capital apregoa, nos discursos difusores de seus projetos de hegemonia, que as relações com o Trabalho devem se regidas pelos princípios da cooperação, da parceria, da busca de objetivos comuns. Essa permanente volta ao tema, reelaborado a partir de novas matrizes discursivas e/ou simbólicas, evidencia que os antagonismos fundamentais, mesmo quando recalcados ou velados, encontram-se em permanente estado de latência na sociedade, podendo emergir sob diferentes formas de manifestação, uma vez que o conflito estrutural não é superado.

Na Era Vargas já se apregoava a colaboração entre o Capital e o Trabalho, como pode ser depreendido da afirmação de Marcondes Filho, Ministro do Trabalho, Indústria e Comércio de Getúlio, de 1942 a 1945: "Se a colaboração entre capital e trabalho já era grande, deve 
tornar-se intensa. Se o espírito conciliativo era uma intenção, precisa transformar-se em hábito. Já afirmei (...) que todo o pensamento dedicado à discórdia é um pensamento roubado à nação" (Marcondes Filho. Apud. Gomes, 1988, p.257 - grifo meu).

Outro discurso ministerial retoma o mesmo ponto, na solenidade de premiação do Operário-Padrão.[10] escolhido em 1983, na vigência da ditadura militar:

[Os trabalhadores brasileiros] estão, hoje, convencidos de que somente a negociação, o diálogo, a tolerância e o equilíbrio permitirão que se alcance o denominador comum de suas aspirações e do interesse nacional. [...] O que vamos todos conseguir esterilizando o radicalismo; é o que todos desejamos: a paz (Apud. Colbari, 1995, p.97).

Já no final da década de 1980, Albano Franco, então Presidente da CNI, em evento semelhante, no qual se premiava o agora designado Operário-Brasil, assim se manifestou sobre a importância de negar a idéia de luta de classes:

A solenidade de premiação do operário-padrão é propícia para repudiar os que pregam a 'luta de classes', e reafirmar seu caráter de elemento de união entre empresários e trabalhadores, que traduz o reconhecimento público do empresariado industrial em relação à classe operária (Idem, p.105).

Não é outro o espírito que marca a afirmação da CNI no ano de 1993:

as atuais condições das forças produtivas, que dão destaque às subjetividades do trabalhador e que, através das novas tecnologias alteram a organização hierárquica das empresas exigindo melhor relação entre os diferentes níveis hierárquicos, põem em cheque o clássico embate capital/trabalho, base sobre a qual se assentou, tradicionalmente, grande parte das teses educacionais. (CNI. 1993, p.2).

A proposta de aliança e cooperação entre o Capital e o Trabalho, um dos pilares do discurso sobre a modernidade difundido no país, nada tem, portanto, de nova. Trata-se, apenas, como assinalou Jameson (1994) de reapresentar o familiar em novos termos, reembaralhando valores e sentimentos. A ênfase na aliança, nas relações harmônicas entre Capital e Trabalho, nega a dimensão política dessas relações e esvazia os espaços próprios de organização dos trabalhadores, sobretudo quando, em tais espaços, visa-se construir reações contra-hegemônicas.

É nova, entretanto, a forma como o discurso dominante busca resolver a questão da identidade social que, desde a Era Vargas, é construída a partir da perspectiva do coletivo, da corporação, reforçada, inclusive, pela estrutura sindical tutelada. Aqui, podemos identificar um processo de ruptura no qual se promove a interiorização de novas identidades pessoais, em que os indivíduos prescindem de referências coletivas para se situarem num novo modelo de sociedade que supervaloriza a individualidade. Nesse sentido, a lógica totalizadora da compreensão do real transfere-se para a competitividade e, conseqüentemente, para o mercado, que assume o papel de regulador de um novo contrato social centrado no indivíduo. É sobre essas bases que se constrói, para os trabalhadores, o novo projeto identificatório apresentado pelo Capital.

Nessa perspectiva, os indivíduos só são efetivamente ativos e produtivos na medida em que os padrões estabelecidos a partir de critérios basicamente econômicos têm suas 
metas atingidas. Assim, o mercado torna os indivíduos abstrações, absolutiza e acentua determinados atributos humanos, enquanto prescinde de outros e os desqualifica, por não serem adequados a atual fase de expansão e consolidação do capitalismo. Assim, o que indagava Kosik mostra-se dotado de grande atualidade: "Que tipo de homem, dotado de que particularidades psíquicas, deve ser criado pelo sistema, a fim de que o próprio sistema possa funcionar?" (1969: 84)

É nesse campo que se situam as reflexões sobre o projeto identificatório, constituído por um conjunto de proposições formuladas por um grupo, por uma fração de classe ou por uma classe, que objetiva manter ou conquistar a hegemonia sobre outros grupos, frações de classe ou, mesmo, sobre a totalidade social e, largamente difundido pelos aparelhos de hegemonia. Esse conjunto de proposições se apresenta como um modelo carregado de positividades, com o qual é necessário identificar-se para assegurar - segundo a concepção de seus formuladores - a inserção exitosa, individual e/ou coletiva, em um dado momento histórico.

Um projeto identificatório só pode tornar-se hegemônico, isto é, só pode ser efetivamente acolhido e "reconhecido" como passível de investimento afetivo, se aqueles a quem se destina nele identificarem um caráter de certeza em sua factibilidade, mesmo que tal certeza seja ilusória. Para que o acolhimento e o reconhecimento ocorram, torna-se fundamental o apelo ao plano psíquico, que constitui característica essencial do projeto identificatório.

Num primeiro momento, o projeto identificatório é formulado por aqueles que detêm, ou pretendem deter, a hegemonia. Essa formulação inicial é construída a partir de diversos elementos, entre os quais os que provêm da concepção de mundo daqueles a quem o projeto visa a atingir, que são incorporados de forma subordinada. Num segundo momento, os destinatários do projeto, que a ele aderem, transformam-se em novos enunciadores do projeto identificatório original, conferindo-lhe, ainda, maior legitimidade.

Um aspecto fundamental de tais projetos reside no fato, já mencionado, de que as aspirações identificatórias formuladas investem, sempre, no futuro; mas num futuro particular, no qual não cabe a idéia de retorno ao passado. Como afirma Mendonça, "o futuro tem um papel essencial no jogo constitucional do projeto identificatório" (s.d., p.20). É precisamente esse investimento no futuro que preserva, pelo menos temporariamente, os formuladores do projeto identificatório do confronto com a realidade, que pode, ou não, afiançar sua validade.

É preciso destacar, entretanto, que essa ênfase no futuro tem, predominantemente, um caráter de exterioridade, uma vez que na lógica interna do discurso, renomeados e redefinidos, são identificados valores ou objetivos recorrentes - como por exemplo, a negação do conflito estrutural entre Capital e Trabalho, e até mitos arcaicos que impregnam a cultura de uma dada sociedade. O projeto identificatório neoliberal 
exemplifica, com clareza, o aqui afirmado.

Ao difundir seu projeto, o Capital antecipa, para o trabalhador, tanto o futuro do país quanto o seu próprio, em que o êxito e, consequentemente a felicidade, estão assegurados. Uma vez que a meta é o futuro, o discurso não pode ser desmentido no plano do senso comum,[11] que predomina na concepção de mundo da sociedade, sobretudo porque o anúncio desse êxito é, cotidianamente, reforçado pelos aparelhos de hegemonia, em particular, pelos meios de comunicação de massa. Se a realidade ainda parece adversa, isso decorre do fato de que as condições para que o futuro anunciado se viabilize ainda não foram atingidas. Como exemplo, podemos destacar o discurso que desloca para as questões educacionais a superação das adversidades vivenciadas, atualmente, pela classe trabalhadora, a qual ainda carece de solução efetiva e pressupõe um investimento ativo de cada um no sentido de buscar aquela formação requerida pelo mercado.

O projeto identificatório elaborado pelo Capital constitui o primeiro momento de sua formulação, como anteriormente assinalado. Nesse momento, as forças dominantes, coerentemente com a postura tutelar em relação à classe trabalhadora, bem como com a luta pela manutenção da hegemonia, se mostram como as decifradoras e porta-vozes das aspirações da dessa classe, apresentando sua proposta como a verdade que representa o desejo do outro e ordena sua percepção da realidade.

Ênfase no novo momento histórico - que na realidade significa o novo estágio tecnológico e gerencial da produção -; na nova identidade do trabalhador, que, supostamente, o coloca no centro do processo produtivo; na nova educação que qualifica para a modernidade; na subordinação das máquinas ao homem; na liberdade adquirida com a nova formação e com a nova forma de organização do trabalho; na coragem para vencer desafios e na competitividade. Eis os pontos centrais do projeto identificatório ora apresentado, ao trabalhador, pelo Capital.

Esse projeto identificatório convida a investir no presente, visando ao futuro promissor. Seu conteúdo, de fácil apreensão, reveste-se de duas características básicas: a) a prevalência do maniqueísmo, expresso na divisão do mundo entre aqueles que são modernos e que apostam no futuro anunciado, e os anacrônicos, que não conseguem desvencilhar-se de um passado cujos valores se mostram inadequados ao novo momento histórico; b) o caráter de funcionalidade em relação às demandas econômicas que lhe dão suporte.

Para o êxito da modernidade anunciada, é necessário que o trabalhador perceba de outra forma a realidade e redefina, a partir dessa nova percepção, sua cidadania. Deve, assim, deixar de considerar-se um agente político para tornar-se um agente econômico, um consumidor, indivíduo potencialmente vencedor nos processos competitivos; portador intrínseco do êxito, que só depende de seu empenho pessoal e de sua capacidade. O tom otimista e conciliador desse projeto identificatório encerra, entretanto, uma velada ameaça: 
apenas os trabalhadores que assumirem o novo perfil estarão aptos a integrarem a economia competitiva. Assim, no bojo do discurso integrador, já está posta a justificativa do possível fracasso, resultado estrito de limitações de caráter individual.. Na realidade, a integração exitosa ao sistema constitui um suposto, e raramente alcançável, prêmio para os trabalhadores que aderirem, integralmente, à proposta de conciliação de classes.

\section{Indicações acerca da contribuição da psicanálise}

Muitos são os fatores de caráter afetivo que se explicitam nos estudos até aqui desenvolvidos, com o objetivo de compreender os processos que determinam o grau de apreensão de um determinado projeto indentificatório, tornando-o (ou não) hegemônico. Procurou-se, até aqui, destacar a importância da dimensão afetiva na conquista e manutenção da hegemonia. Esses estudos apontam para a necessidade de ampliar 0 referencial de análise, buscando no campo da psicologia - e, em particular, da psicanálise - elementos que permitam compreender, de modo mais aprofundado, como determinadas concepções de mundo se tornam hegemônicas; como se constitui a validade psicológica das ideologias ou como se estruturam as dinâmicas psicossociais das instâncias da sociedade civil.

Vários teóricos marxistas, como o próprio Gramsci, referem-se, em seus escritos, a questões de ordem psicológica. Pode-se destacar como exemplo, seu estudo Americanismo e fordismo, onde analisa o modo como a organização industrial, constituída a partir do taylorismo e do fordismo, apresenta àqueles que dela participam um determinado conjunto de exigências de caráter psicofísico: "a vida na indústria exige um tirocínio geral, um processo de adaptação psicofísica para determinadas condições de trabalho, de nutrição, de habitação, de costumes etc" (1984, p.391). Destaca, assim, o fato de que para se integrar a determinado modo de organização produtiva, os indivíduos devem, além de criar e/ou adaptar comportamentos motores e cognitivos, elaborar uma nova maneira de pensar que seja intrínseca à sua ação.

Esse processo, vivenciado pelos trabalhadores ao longo da história, se agudiza sobremaneira no contexto contemporâneo do trabalho, dada à velocidade das transformações tecnológicas e ao modo como são impostas aos trabalhadores. As crescentes mudanças no trabalho levam a um contínuo redimensionamento do agir individual e coletivo, exigindo constantes processos de adaptação. Tal adaptação, entretanto, não se dá de forma automática, seja no plano motor, cognitivo ou afetivo. Ao contrário, os novos comportamentos devem ser mediados por um conjunto de representações que convença os indivíduos, que torne o gesto natural e determinado pela vontade de quem o realiza.

Nesse sentido, tanto os trabalhadores que mantêm postos de trabalho nos setores com os quais estão familiarizados, quanto aqueles que passam a ser desnecessários e que irão aumentar o contingente dos que sobrevivem na economia informal ou buscam, em 
processos de requalificação, ocupar postos de trabalho em outros ramos produtivos terão, forçosamente, de criar novas formas de agir e pensar. Esses processos de adaptação não se restringem à situação de ocupação - seja ela qual for - mas se fazem presentes em todas as instâncias individuais e coletivas de vida, transformadas para dar sustentação a todo um novo ordenamento societário necessário à nova etapa de expansão do Capital. É a compreensão de tais processos, em sua complexidade, que aponta para a possibilidade de ampliação do referencial de análise, com o recurso da psicanálise.

Ao propor tal encaminhamento para os estudos teóricos sobre o projeto identificatório, não se ignora o fato de que estamos diante, no marxismo e na psicanálise, de ontologias distintas. Entretanto, também se faz necessário compreender que, há uma aproximação entre ambos, já que, em seus escopos teóricos, propõem a análise dos movimentos do real para além dos discursos manifestos, visando a apreender a essência de seu sentido.

Consideramos, portanto, ser possível a apropriação de fundamentos da psicanálise a partir de importante indicação teórico-metodológica de Gramsci, no que tange à construção do conhecimento, embora devamos destacar que a psicanálise não constitui um "adversário", nem "pensamento passado", sendo ao contrário, atual e subversiva em relação à visões cristalizadas sobre o homem.

"Na discussão científica, já que se supõe que o interesse seja a pesquisa da verdade e o progresso da ciência, demonstra ser mais 'avançado' quem se coloca do ponto de vista segundo o qual o adversário pode expressar uma exigência que deva ser incorporada, ainda que como momento subordinado, na sua própria construção. Compreender e valorizar com realismo a posição e as razões do adversário (e o adversário é, talvez, todo o pensamento passado) significa justamente estar liberto da prisão das ideologias (no sentido pejorativo, de cego fanatismo ideológico), isto é, significa colocar-se em um ponto de vista 'crítico'. O único fecundo na pesquisa científica (Gramsci, 1978, p.31).

Não se pode, entretanto, desconhecer as críticas que tanto Gramsci quanto Freud, apresentaram, o primeiro à teoria psicanalítica e o segundo ao marxismo. Tais críticas, entretanto, derivaram, sobretudo, do desconhecimento de ambos acerca do que criticavam.

Referindo-se a Freud, Gramsci afirma: "Não pude estudar as teorias de Freud e não conheço o outro tipo de literatura chamada 'freudiana'"(Gramsci, 1999, p.229). Apesar disso, o filósofo italiano considerava que "o freudianismo é mais uma ciência a ser aplicada às classes superiores, e se poderia dizer, parafraseando Bourget (...), que o 'inconsciente' só começa depois de algumas dezenas de milhares de liras de renda" (Idem, p.265). O filósofo italiano também afirma: "Não creio no fundamento científico da psicanálise, ou, pelo menos, creio ser necessário restringir muito sua esfera real. (...) A psicanálise deu uma forma atual ao diabo, chamado-o de 'inconsciente' ou 'subconsciente'" (Gramsci, 2002, p.381).

Já para Freud,

o marxismo teórico tal como foi concebido no bolchevismo russo, adquiriu a energia e o caráter auto-suficiente de uma Weltanschauung; contudo, adquiriu ao mesmo tempo, 
uma sinistra semelhança com aquilo contra o que está lutando. Embora sendo originalmente uma parcela de ciência, e construído, em sua implementação, sobre a ciência e a tecnologia, criou uma proibição para o pensamento que é exatamente tão intolerante quanto o era a religião no passado (1976, p.218).

Tal como na Conferência XXXV, acima citada, também em $O$ mal-estar na civilização, Freud, defende a idéia de que a força do marxismo reside na importância que atribui aos fatores econômicos. Entende, porém, que eles não são o determinante único do comportamento humano. Para o teórico, os fatores de ordem psicológica e o próprio processo de desenvolvimento cultural não podem deixar de ser levados em conta. Não se pode, assim, deixar de destacar a importância da cultura para a sustentação de uma dada formação sócio-econômica, do mesmo modo como Gramsci sublinhou em sues escritos.

Konder, em artigo onde analisa a visão de Freud sobre o pensamento de Marx, decorrente, principalmente, das influências de Alfred Adler e Wilhelm Reich, nos apresenta uma autocrítica do teórico da psicanálise acerca da questão, formulada dois anos antes de sua morte:

Sei que os meus conhecimentos sobre o marxismo não revelam nenhuma familiaridade maior, não mostram uma compreensão adequada dos escritos de Marx e Engels. Fiquei sabendo mais tarde, com certa satisfação, que nem um nem o outro negaram a influência dos fatores do ego e do superego. Isso desfaz o principal conflito que eu pensava existir entre o marxismo e a psicanálise (Freud. Apud Konder, 1984, p.113).

Não se pretende, neste ensaio, tratar, de modo aprofundado, das relações entre o marxismo e psicanálise, objeto de vasta literatura na qual se destacam, sobremaneira, os estudos dos integrantes da Escola de Frankfurt, já mencionados. Nosso propósito aqui, consiste, estritamente, em indicar contribuições da teoria psicanalítica que podem concorrer, segundo nosso entendimento, para uma compreensão mais plena dos processos de conquista e manutenção da hegemonia. Aprofundar tal compreensão, entretanto, exige a realização de estudos teóricos que vão além dos limites deste trabalho e, mesmo, de nossa formação, demandando trabalhos de caráter interdisciplinar, que fogem aos objetivos previamente propostos por nós.

Os fundamentos da teoria psicanalítica não são estranhos às discussões aqui apresentadas, concorrendo, como vimos, para a formulação da categoria projeto identificatório, a partir dos estudos desenvolvidos por Aulagnier (1985) e Mendonça (s.d). Ao longo do presente trabalho foram feitas diversas referências às necessidades humanas de ancorar suas ações e projetos de vida, individuais e coletivos, em valores que se apresentem seguros, em enunciações que acenem para possibilidades de vida individual e coletiva estável e/ou potencialmente ascendente.

Ou seja, os elementos da concepção de mundo difundidos com o propósito de assegurar a conquista e manutenção da hegemonia devem, necessariamente, ser percebidos, pelos grupos societários a serem conquistados, com anunciadores de um futuro considerado desejável, revestido de positividades que assegurem, mesmo que ilusoriamente, a possibilidade de conquista da felicidade. É, precisamente, a promessa de obtenção da 
felicidade que se apresenta como o elemento fundamental, nas relações que estabelecemos com a teoria psicanalítica, como será abordado adiante.

Gramsci afirma que uma das principais características da hegemonia consiste em subordinar intelectualmente as demais classes pela persuasão e pela educação. Faz também, em seus escritos, várias referências à necessidade de que a hegemonia esteja assentada em contatos sentimentais e ideológicos. Assim, consideramos que sua própria concepção de hegemonia abre a possibilidade de entendermos que, para conquistá-la, como já afirmado, não é possível prescindir da esfera afetiva. A referência ao fato de que a expansividade de uma força que seja ou se pretenda hegemônica, exige a penetração em todas as dimensões da vida, por si só evidencia que tal processo não se opera, estritamente, no plano da racionalidade.

E é, precisamente, no âmbito da afetividade que recebem acolhida as promessas de inserção exitosa em dado momento histórico; os apelos de investimento em um futuro aparentemente assegurado, mesmo que demande no presente, sacrifícios e privações; o convite para o envolvimento individual e coletivo com projetos societários que sejam, mesmo que apenas supostamente, factíveis.

Em O futuro de uma ilusão, Freud irá ocupar-se da questão da cultura, a qual atribui um significado tão complexo, quanto amplo. Para ele,

A civilização humana, expressão pela qual quero significar tudo aquilo em que a vida humana se elevou acima de sua condição animal e difere da vida dos animais (...) apresenta, como sabemos, dois aspectos ao observador. Por um lado, inclui todo o conhecimento e capacidade que o homem adquiriu com o fim de controlar as forças da natureza e extrair a riqueza desta para a satisfação das necessidade humanas, por outro, inclui todos os regulamentos necessários para ajustar as relações dos homens uns com os outros e, especialmente, a distribuição da riqueza disponível (1974, p.16)

Aqui, deparamos com a necessidade de formular indagações que se fazem obrigatórias na perspectiva do materialismo histórico, tais como: qual a perspectiva de Freud quanto à à distribuição da riqueza? A quem caberia a tarefa e o poder de estabelecer os regulamentos ordenadores de um determinado modelo societário? Indicações acerca das respostas podem ser encontradas quando o autor afirma ter a impressão de que a "civilização é algo que foi imposto a uma maioria resistente por uma minoria que compreendeu como obter a posse dos meios de poder e coerção" (Idem, p.16). Acrescenta, ainda, que os problemas relativos à civilização não são inerentes à sua natureza, mas dizem respeito à imperfeição das formas culturais até então desenvolvidas (Idem, p. 17).

Tais afirmações permitem considerar que a vertente social da análise freudiana, embora pouco aprofundada, abriga possibilidades de intercessão, tanto com as reflexões que podem decorrer do conceito de Estado em Marx, associado, essencialmente à coerção, quanto com a concepção gramsciana de cultura, na qual se explicita a necessidade de uma reforma intelectual e moral para a superação da ordem capitalista. Para Gramsci, por exemplo em Americanismo e fordismo, identifica-se duas naturezas no homem; a primeira 
natureza, marcada pela "animalidade" (1984, p.393) e pelos instintos, e a "segunda natureza" (Idem, p.393), ou seja, um novo "modo de vida", ou "novos tipos de civilização" (Idem, p.393).

Freud, por um lado, considera que as massas não são capazes de conduzir seu próprio destino, em grande parte pela tendência destrutiva que identifica nos seres humanos (tal convicção o leva, assim, a dedicar-se não à análise das questões materiais, mas aos problemas mentais). Por outro lado, entretanto, ao manifestar-se acerca de questões relativas à cultura, também em $O$ futuro de uma ilusão, afirma:

Se, porém, uma cultura não foi além do ponto em que a satisfação de uma parte de seus participantes depende a opressão de outra parte, parte esta talvez maior - e este é o caso em todas as culturas atuais -, é compreensível que as pessoas assim oprimidas desenvolvam uma intensa hostilidade para com a cultura cuja existência elas tornam possível pelo seu trabalho, mas de cuja riqueza não possuem mais do que uma cota mínima (1974, p.23).

Uma sociedade, entretanto, não pode sustentar-se, tão somente, nos mecanismos de coerção. É necessário que os homens encontrem, na vida societária, satisfações e recompensas por seus sacrifícios. Para o teórico, religiões, manifestações artísticas e xenofobia, podem constituir elementos fundamentais para assegurar a satisfação necessária à manutenção das condições de subordinação. O que é fundamental nesse caso é que o foco da satisfação esteja na natureza narcísica, de modo a criar possibilidades de que os oprimidos se identifiquem com seus dominadores. A esse respeito, afirma: "As classes oprimidas podem estar emocionalmente ligadas a seus senhores; apesar de sua hostilidade para com eles, podem ver neles seus ideais" (Idem. p.24-5).

Entendemos que tanto o fato de oferecer às classes subalternizadas a possibilidade de partilhar de ideais que teoricamente são de todos, quanto à difusão da idéia ilusória de que a adesão ao proposto pelas forças dominantes pode possibilitar que os dominados se tornem iguais ou semelhantes aos que os dominam, constituem aspectos centrais da acolhida do projeto identificatório hegemônico no âmbito do modo de produção capitalista. Explicitam-se, assim, elementos de reflexão que não podem ser ignorados quando nos debruçamos sobre a importância, a complexidade e o alcance da hegemonia e sobre o papel fundamental dos aparelhos de hegemonia.

Em estudo anterior, ao abordarmos a dinâmica dos processos de elaboração, apropriação e re-elaboração das ideologias, essenciais, como nos mostra Gramsci, à conquista, manutenção ou superação de uma dada hegemonia, afirmamos que os "limites demarcados pelas origens de classe são determinantes, mas não constituem o único elemento explicativo da circulação, apreensão ou rejeição de idéias, valores e concepções que prevalecem no plano interno de uma classe, ou de uma fração de classe" (Rummert, 2000. 31).

Essa perspectiva vai ao encontro de análise que Freud formula acerca do que considera 
um limite da visão materialista da história, no que se refere às ideologias, por não considerar a importância do superego. Para ele,

Parece provável que aquilo que se conhece como visão materialista da história peque por subestimar esse fator. Eles o pões de lado, com o comentário de que as 'ideologias' do homem nada mais são do que produto e superestrutura de suas condições econômicas contemporâneas. Isso é verdade, mas muito provavelmente não a verdade inteira. A humanidade nunca vive inteiramente no presente. $O$ passado, a tradição da raça e do povo, vive nas ideologias do superego e só lentamente cede às influências do presente, no sentido de mudanças novas; e, quando opera através do superego, desempenha um poderoso papel na vida do homem, independente das condições econômicas (Freud, 1976, p.87)

Em $O$ esboço de psicanálise, Freud nos apresenta, ao referir-se às relações entre o ego e o superego, elementos que nos permitem compreender em que medida a estrutura psíquica dos indivíduos constitui elemento fundamental no processo de acolhida ou rejeição de um projeto identificatório, permitindo, ainda, que assinalemos a importância fundamental da cultura nesse processo. Do mesmo modo, podem estar abrigadas, nas categorias ego e superego, explicações para aspectos que Konder destaca, como a longa duração do imaginário coletivo e a influência dos mitos arcaicos no comportamento societário. Segundo o pensador vienense,

Os pormenores da relação entre o ego e o superego tornam-se completamente inteligíveis quando são remontados à atitude da criança para com os pais. Essa influência parenteral, naturalmente, inclui em sua operação não somente a personalidade dos próprios pais, mas também a família, as tradições raciais e nacionais por eles transmitidas, bem como as exigências do 'milieu' social imediato que representam. Da mesma maneira, o superego, ao longo do desenvolvimento de um indivíduo recebe contribuições de sucessores e substitutos posteriores dos pais, como professores e modelos, na vida pública, de ideais sociais admirados" (Freud, 1975, p.171).

Entendemos serem tanto as tradições sócio-culturais, geradas no interior do modo de produção capitalista, quanto os modelos que emergem da vida pública, de forma espontânea ou artificialmente gerados pelas forças dominantes e difundidos pelos aparelhos de hegemonia, pilares da construção e apropriação do projeto identificatório hegemônico ou que se pretende hegemônico. Retomando-se a visão de Freud, acerca do fato de que os subalternizados podem, simultaneamente, estar emocionalmente ligados aos dominantes, apesar de desenvolverem, também, em relação a eles sentimentos de hostilidade, encontramos nas formulações da psicanálise a possibilidade de compreender, de forma mais ampliada os processos já destacados em Gramsci.

\section{Conclusão}

Na realidade, é possível depreender, do até aqui exposto, que na teoria psicanalítica, estão postas relações estreitas entre a estrutura psíquica, a formação cultural de uma dada sociedade e a base em que tal formação se estrutura e com a qual interage permanentemente, que é a organização econômica. Tais constatações, por um lado, não apontam para a solução de impasses que teóricos dos dois campos apontam como impeditivos de diálogo. Entretanto, evidenciam que há, ainda, um longo caminho a 
percorrer no que se refere à compreensão da riqueza que pode derivar da busca de uma aproximação teórica, livre de preconceitos dogmáticos, entre o materialismo histórico e a psicanálise.

As teses socialistas são, várias vezes, abordadas por Freud, que aponta nelas aspectos que considera pertinentes mas as apresenta, sempre, como encerradas em impasses decorrentes da concepção de homem em que se sustentam. Em $O$ mal-estar na civilização, irá, mais uma vez, destacar tal fato ao afirmar, sobre as mudanças necessárias para a construção de um novo modelo societário:

Acho também bastante certo que (...) uma mudança real nas relações dos seres humanos com a propriedade seria de muito mais ajuda do que quaisquer ordens éticas; mas o reconhecimento desse fato entre os socialistas foi obscurecido, e tornado inútil para fins práticos, por uma nova e idealista concepção equivocada da natureza humana (1974, p.168)

Para o teórico da psicanálise, o equívoco dos comunistas, ou socialistas, como denomina, indistintamente, os formuladores do materialismo histórico e seus seguidores, reside na crença de que o homem é intrinsecamente bom, do mesmo modo que o é sua disposição em relação aos demais homens. Nessa perspectiva, a natureza humana foi corrompida pela propriedade privada. O poder por ela conferido aos homens dá origem à opressão, a qual, por sua vez, gera a hostilidade contra o opressor. Assim, sendo abolida a propriedade privada, essas conseqüências, tais como a agressividade e a hostilidades desapareceriam. Freud afirma não desejar se deter nas críticas de caráter econômico do comunismo; considera, apenas, que essas premissas psicológicas em que ele se baseia são "uma ilusão insustentável". Afirma, em síntese, que a abolição da propriedade privada não altera a natureza da agressividade, a qual considera "o maior impedimento à civilização" e a geradora dos conflitos (Idem, p 134-135; 144).

Entretanto, como assinala Konder, em O mal-estar na civilização, principalmente, Freud polemiza com as idéias de Reich, supondo que as mesmas apresentavam fielmente o pensamento de Marx. O teórico da psicanálise atribuía ao marxismo significativo grau de ingenuidade por supor que a agressividade humana decorria, estritamente, da propriedade privada e por crer que ser possível chegar a uma sociedade capaz de prescindir de qualquer mecanismo de coerção. Para tais críticas

contribuíam certamente o pessimismo de Freud, seu ceticismo em relação à natureza humana. Mas as acusações de decorriam também da confusão estabelecida por Reich entre suas próprias concepções e aquelas que ele atribuía a Marx. Na realidade, Marx dificilmente subscreveria algumas teses de Reich que Freud estava criticando (Konder, 1984 , p. 112).

Apresentamos, neste ensaio, ponderações sobre divergências e possibilidades de convergência entre o marxismo e a psicanálise, bem como sobre elementos da teoria freudiana- em particular sobre os elementos constitutivos do superego, o papel preponderante da cultura, bem como a importância das questões relativas à agressividade, que podem permitir, em estudos ulteriores de caráter interdisciplinar, uma melhor 
compreensão dos processos individuais e coletivos em jogo nas disputas por hegemonia.

O exposto ao longo deste ensaio evidencia o fato de que abordar uma realidade cultural, na qual se inscrevem projetos identificatórios gerados na disputa política por hegemonia, é tratar de um processo dinâmico em que se mesclam, de forma intensa, elementos da racionalidade e da afetividade. Ao longo da história do modo de produção capitalista ocorreram transformações de diferentes ordens em meio às quais as análises de caráter político, social e econômico evidenciam a permanência de marcas e entraves do passado, presentes nas formas como hoje o mundo é percebido e transformado em representações que regem a dinâmica emocional e cognitiva das diferentes classes e frações de classe.

Nesse quadro, é necessário reconhecer que diferentes frações da classe trabalhadora apresentam demandas e aspirações e buscam soluções para seus problemas e necessidades de formas distintas das expectativas de muitos dos que se dispõem a compreender suas características e a apontar caminhos de superação da ordem existente.

Em seus escritos do cárcere, Gramsci indaga:

O que é que o homem pode se tornar? (...) não é uma pergunta abstrata ou 'objetiva'. Ela nasce do fato de termos refletido sobre nós mesmos e sobre os outros; e de queremos saber, de acordo com o que vimos, e refletimos, aquilo que somos, aquilo que podemos se, se realmente - dentro de que limites somos çriadores de nós mesmos', da nossa vida, do nosso destino (1978, p.38).

Entendemos que os elementos da teoria psicanalítica podem concorrer, de forma significativa para uma melhor compreensão dos processos que regem o pensar e o agir das classes subalternizadas, possibilitando a formulação de respostas à questão formulada por Gramsci mais amplas e potenciadoras de efetivas ações políticas que concorram para a transformação, na medida em que nos oferece ricos elementos para a compreensão do homem para além das determinações econômicas, sem, entretanto, ignorá-las ou minimizar-lhes a importância.

\section{Referências Bibliográficas}

ANSSART, Pierre. Ideologias, conflitos e poder. Rio de Janeiro: Zahar, 1978a.

AULAGNIER, Piera. Os destinos do prazer. Rio de Janeiro: Imago, 1985.

BARBIER, Renné. Soobre o imaginário. Em aberto. Brasília, DH, ano 14, n.61, jan/mar. 1994.

BOBIO, Norberto. Oconcdeito de sociedade civil. Rio de Janeiro, Graal, 1982.

BUCI-GLUCKSMANN, Cristine. Gramsci e o Estado. São Paulo: Paz e Terra, 1980.

CONFEDERAÇÃO NACIONAL DA INDÚSTRIA. Educação básica e formação profissional: uma visão de empresários. Salvador, 1993.

COLBARI, Antonia. Ética do trabalho. São Paulo: Letra \& Letra, 1995. 
COUTINHO, Carlos Nelson. Fontes do pensamento político - Gramsci. Porto Alegre, L\&PM, 1981.

FAUSTO Boris. Trabalho urbano e conflito social. São Paulo: Difel, 1987.

FREUD, Sigmund. O esboço de psicanálise Edição Standard Brasileira. Rio de Janeiro: Imago Editora, 1975. Vol. XXIII.

O futuro de uma ilusão. Edição Standard Brasileira. Rio de Janeiro: Imago Editora, 1974. Vol.XXI.

. O mal-estar na civilização. Edição Standard Brasileira. Rio de Janeiro: Imago Editora, 1974. Vol.XXI

Novas conferências introdutórias sobre psicanálise. Conferência XXXV. Edição Standard Brasileira. Rio de Janeiro: Imago Editora, 1976. Vol. XXII.

GRAMSCI, Antonio. Concepção dialética da história. $2^{\underline{a}}$ ed. Rio de Janeiro, Civilização Brasileira, 1978a.

- Literatura e vida nacional. $3^{\underline{a}}$ ed. Rio de Janeiro, Civilização Brasileira, 1978b.

. Maquiavel, a política e o Estado Moderno. $4^{\underline{a}}$ ed. Rio de Janeiro, Civilização Brasileira, 1980.

. Cadernos do cárcere. Rio de Janeiro: Civilização Brasileira, 1999. v.1; 2002:

v.6.

GRUPPI, Luciano. O conceito de hegemonia em Gramsci. Rio de Janeiro: Graal, 1980.

GOMES, Angela de Castro. A invenção do trabalhismo. Rio de Janeiro: IUPERJ, Vértice, 1988.

HIRARTA, Helena. Da polarização das qualificações ao modelo de competência. In: FERRETTI, Celso et. al. Novas tecnologias, trabalho e educação: um debate multidisciplinar. 2.ed. Petrópolis: Vozes, 1994.

JAMESON, Fredric. Espaço e imagem. Teorias do pós-moderno e outros ensaios. Rio de Janeiro, Editora da UFRJ, 1994.

KONDER, Leandro. O marxismo na batalha das idéias. Rio de Janeiro: Nova Fronteira, 1984.

. Esquerda, socialismo e marxismo. Teoria \& pesquisa. São Carlos: n.2, set. 1992a.

O futuro da filosofia da práxis. O pensamento de Marx no século XXI. Rio de Janeiro: Paz e Terra, 1992b.

KOSIK, Karel. Dialética do concreto. Rio de Janeiro: Paz e Terra, 1978. 
KROEBER, A. L. Ethos. Dicionário de Ciências Sociais. Rio de Janeiro: FGV/Unesco, 1986.

LEFEBVRE, Henri. Lógica formal / lógica dialética. Rio de Janeiro: Civilização Brasileira, 1979.

MARX, Karl e ENGELS, Friedrich. A ideologia alemã. São Paulo: Ciência Humanas, 1979.

MANACORDA, Mario A. La alternativa pedagógica. Barcelona: Nova Terra, [s.d.].

MENDONÇA, Sonia Regina de. Os vetores da fantasia: modernização e progresso num discurso político da Primeira República. Revista de psicologia do Departamento de Psicologia da UFF, Niterói, [s.d.]

PORTELLI, H. Gramsci e o bloco histórico. São Paulo, Paz e Terra, 1987.

RUMMERT, Sonia Maria. Educação básica, formação técnico profissional e qualificação. Convergências e divergências entre capital e trabalho no atual quadro de reestruturação produtiva. Relatório final CNPq - Bolsa de Produtividade. Rio de Janeiro: 2002.

SADER, Eder. Quando novos personagens entram em cena. Rio de Janeiro: Paz e Terra, 1988.

THOMPSON, Edward. A formação da classe operária inglesa: árvore da liberdade. Rio de Janeiro: Paz e Terra, 1987.

(*) Professora Adjunta da Faculdade de Educação e do Programa de Pós-Graduação em Educação da Universidade Federal Fluminense. Pesquisadora do CNPq e do NEDDATE.

[1] Nos valeremos, aqui, predominantemente, das antigas publicações da obra de Gramsci, em português, visto que a nova edição, GRAMSCI, Antonio. Cadernos do cárcere. Vols. 1 a 6. Rio de Janeiro: Civilização Brasileira, 1999-2002, por apresentar o conteúdo completo dos cadernos, não permite localização rápida de trechos anteriormente destacados.

[2] Ver Rummert, S. M. 1998a, 1998b, 2000, 2001.

[3] A expressão projeto identificatório é utilizada sob a influência do estudo de Mendonça (s.d.) e de Aulagnier (1985). Cabe, ressaltar, que a expressão projeto identificatório designa genericamente o que Freud denominou como "ideal de ego", e representa a condição essencial de existência, tanto do Eu individual como do Eu coletivo. Desta concepção, o que requer destaque no presente trabalho é o fato, assinalado pelas autoras, de que um projeto identificatório só se torna hegemônico, isto é, só é efetivamente acolhido e reconhecido como passível de investimento (emocional e afetivo) pelo outro (indivíduo e/ou grupo) quando se reveste, para esse outro, de um caráter de certeza em sua facibilidade, mesmo que tal certeza seja ilusória.

[4] Para a compreensão de aspectos frágeis que hoje se evidenciam no pensamento de Marx - alguns dos quais podem, também, ser identificados no de Gramsci — ver as 
reflexões de Konder (1992a; 1992b).

[5] Utilizo o termo superar no sentido que lhe é atribuído por Lefebvre: Em casa etapa do desenvolvimento da natureza, da vida, do pensamento, o passado reencontrado - mas superado e, por isso mesmo, aprofundado, liberado de suas limitações, mais real que no início, (1979: 231) (grifos do autor).

[6] É importante ressalvar, aqui, embora não integre o referencial teórico deste ensaio, a produção da Escola de Frankfurt, que em sua primeira geração de teóricos (especialmente Horkheimer, Adorno e Marcuse), desenvolveu diversos estudos visando a buscar a complementaridade entre o marxismo e a psicanálise, trabalho esses a serem analisados em momento posterior.

[7] O significado aqui atribuído ao imaginário corresponde, particularmente, ao sentido de imaginário social, como é concebido por Perre Ansart: "toda a sociedade cria um conjunto coordenado de representações, um imaginário através do qual ela se reproduz e que designa em particular o grupo a ele próprio, distribui as identidades e os papéis, expressa as necessidades coletivas e os fins a alcançar. Tanto as sociedade modernas, como as sociedades sem escrita, produzem esses imaginários sociais, esses sistemas de representações, através dos quais elas se autodesignam, fixam simbolicamente suas normas e seus valores." (ANSART, 1978: 21-2). É importante assinalar, ainda, que a abordagem do imaginário neste trabalho visa a elucidar aspectos essenciais à compreensão da problemática da identidade, em sua perspectiva social, que constitui um dos elementos norteadores do estudo aqui desenvolvido.

[8] Esse rico processo de construção de identidades é analisado por Gomes (1988). Deve ser destacado, também, que Boris Fausto (1987) analisou as origens dessa corrente, sob a denominação de trabalhismo carioca, no período compreendido entre o final do século XIX e o início do anos de 1920.

[9] A expressão "ethos empresarial" foi cunhada pela CEPAL, para qualificar as expectativas de geradas em torno da concepção de modernidade. O termo cuja origem está na concepção grega de caráter ou ética, é hoje apropriado, por exemplo, pela sociologia, pela antropologia e pela psicologia. De acordo com a perspectiva deste trabalho, considero adequada a definição que nos é apresentada por Kroeber, para quem ethos corresponde ao sistema de idéias ou valores que dominam a cultura e tendem assim a controlar o tipo de comportamento de um grupo ou de uma sociedade (1986: 433).

[10] Detalhando estudo sobre o tema foi desenvolvido por COLBARI (1995).

[11] Segundo a concepção gransciana, o senso comum pode ser definido como uma formação histórica específica, que possui as características difusas e dispersas de um pensamento genérico de uma certa época, em um certo ambiente popular (GRAMSCI, 1978a: 18). Por não ser sistemático nem suficientemente crítico, o senso comum combina, sem se dar conta disso, idéias profundamente contraditórias, tomadas da ideologia dominante, geradas pelas experiências solidárias de classe, idéias arcaicas e elementos da ciência. 